\title{
19
}

\section{Evapotranspiration and Related Calculations for Bioretention Devices}

\author{
Robert Pitt, Shirley Clark, Pauline Johnson and John Voorhees
}

Bioretention devices are becoming increasing popular stormwater management controls. However, there are many soil processes that affect their performance, and knowledge of these processes and soil characteristics are necessary in order to determine the expected performance of these devices under various conditions. This chapter stresses evapotranspiration (ET) and how it affects the water balance. Other processes discussed in this chapter include clogging from the capture of sediment on the bioretention facility device, cation exchange capacity (CEC) which is one measure of dissolved pollutant retention to protect groundwater, and sodium adsorption ratio (SAR) which can help identify adverse infiltration rate effects due to destabilized clay fractions in the soil. The steps for these analyses outlined here are being integrated into the Source Loading and Management Model (WinSLAMM) (Pitt 1997; Pitt and Voorhees 2002).

\subsection{Introduction}

Bioretention devices are a broad category of emerging stormwater controls that are being applied in many areas of the US, although they are most popular along the east coast. They basically are replacements of older infiltration trenches, but are designed to take advantage of soil processes. Plants are also an important component of most bioretention facilities. They

Pitt, R.E., S. Clark, P. Johnson and J. Voorhees. 2008. "Evapotranspiration and Related Calculations for Bioretention Devices." Journal of Water Management Modeling R228-19. doi: 10.14796/JWMM.R228-19. (C) CHI 2008 www.chijournal.org ISSN: 2292-6062 (Formerly in Reliable Modeling of Urban Water Systems. ISBN: 978-0-9808853-0-9) 
are placed in upland watershed areas to treat source area flows, instead of outfall flows. Common examples are used in parking lot median strips, or rain gardens to treat roof runoff. Evapotranspiration (ET) can be an important aspect of the water balance of these devices, and this chapter shows how these benefits can be calculated. Soil treatment of the percolating water is also important in most bioretention devices. If they have an underdrain, much of the treated water can be returned to the surface having much better water quality (a common strategy in Australia in water poor regions). If no underdrain, or in areas having highly permeable subsoils, the soil can provide important treatment of the water to protect underlying groundwater. Therefore, soil amendments are often used to improve the subsurface treatment of the infiltrating water in bioretention facilities. Many state agencies and NGOs have construction and placement guidance. Common sources of information include the Low Impact Development Center (http://www.lowimpactdevelopment.org/), the Center for Watershed Protection (http://www.cwp.org/), Prince Georges County Low Impact Development Manual (http://www.co.pg.md.us/Government/AgencyIndex/

DER/ESD/low-impact.asp), and the stormwater management programs in Western Washington and Oregon, especially the new examples being built in the Puget Sound area and in Portland, to mention just a few.

There are several steps in a bioretention device water balance calculation. At the end of a rain, the soil may be saturated, or at least above the moisture field capacity (depending on the moisture level before the rain and the rain intensity and depth). The pore space will drain to the field capacity level at a rate (soil in. per h) approximately equal to the infiltration rate (rain in. per h) divided by the void ratio. The remaining available moisture in the soil will then be lost through the plant by evapotranspiration, until the permanent wilting point is reached, or another rain occurs. The following lists the data requirements for this calculation:

1. pore volume of soil (porosity) (fraction of voids to total soil mass)

2. root depth (ft)

3. field moisture capacity for soil (\% of dry weight of soil)

4. permanent wilting point ( $\%$ of dry weight of soil; varies for different soil textures)

5. reference monthly ETo values (average inches per day for each month)

6. crop factor for actual crop compared to reference ET values (decimal multiplier)

7. initial soil moisture conditions at beginning of study period (may be reasonable to assume field capacity) 
8. supplemental irrigation to be used? (automatically turned on before permanent wilting point is reached and then off again before the field capacity is reached; probably between 0.25 and 0.85 of the available capacity, or at another \% moisture level; common in the arid west, especially for green roofs)

9. soil layer depths ( $\mathrm{ft})$

Items 2 and 6 can be a menu for common plants (several turf grasses, several native plant types, etc.), while items 1, 3, 4 can be a menu for soils (different textures with and without amendments; minimal compaction). The following lists the information that needs to be calculated for the mass balance:

- moisture level of soil at beginning of rain

- saturation mass of water for root zone (inches of water for root zone for each soil layers)

- field capacity mass (and wilting point mass) of water for root zone (inches of water for root zone for each soil layers)

An example calculation outline for a bioretention device is as follows:

- Initial starting conditions at field capacity (or at other starting condition specified)

- ET loss until start of first rain (or gravity drain using saturated hydraulic conductivity rate added to ET if initial moisture level is $>$ field capacity)

- Determine moisture deficit to field capacity and deficit to saturation at start of first rain (inches of water for root zone)

- Determine how much of the deficits will be satisfied by the rain event infiltrating water (the deficits are satisfied from the first portion of the infiltrating water)

- Determine soil moisture level at end of rain (\%) and if greater than or less than field capacity

- If moisture level is greater than field capacity, drain soil using saturated hydraulic conductivity rate (Ks) to underlying layers based on porosity times Ks rate until field capacity is reached (determine hours needed to drain to field capacity)

- If moisture level is less than field capacity (and simultaneously with Ks drainage); determine ET moisture loss rate for time until next rain (or until permanent wilting point is reached, or until supplemental irrigation is used). ET during the rain itself is likely quite low due to heavy overcast conditions, lower 
temperatures, and the plant moisture needs are likely satisfied by precipitation interception.

- Determine moisture level at start of next rain and repeat calculations

It should be noted that excess infiltrating water not captured by the root zone moisture deficit is passed to lower layers of the bioretention device for longer term storage, natural infiltration out of the bottom of the device, or drainage through an underdrain. There are many options concerning the soils in a bioretention device, including soil amendments. The main benefit of soil amendments is the increase in the field capacity of the soil and lowering of the permanent wilting point, resulting in larger amounts of moisture being held in the root zone for ET (Pitt, et al. 1999).

\subsection{Summary Data for Bioretention Facility Water Balance Calculations}

The following tables summarize typical data for different soils, amendments, and plants that may be used in bioretention facilities. Table 19.1 (see appendix) shows the following characteristics, compiled from numerous stormwater treatability and urban soil projects (Clark and Pitt 1999; Pitt, et al. 1999; Pitt and Lantrip 2000; Pitt, et al. 2003; Johnson, et al. 2003):

- saturated water content (equal to the porosity),

- field capacity (the gravity drainage limit),

- permanent wilting point (lower moisture level that can be obtained through ET. If the soil moisture level decreases below this value, the plant cannot recover and dies),

- available soil moisture (the volume between the field capacity and the permanent wilting point, expressed in inches of water per inches of soil),

- infiltration rate of the soil (the rate that water can enter the soil surface, with vegetation; soil assumed to be slightly compacted)

- saturated hydraulic conductivity (water movement rate under completely saturated conditions, assuming a unit hydraulic gradient),

- Cation Exchange Capacity (CEC) (calculated capacity of the soil to remove and retain cations, usually expressed in milliequivalents/100 grams),

- dry density of the soil (assumed to be slightly compacted) 
The infiltration rates and saturated hydraulic conductivity for the mixtures should be based on the amount of amendment added (if $10 \%$ or greater), as shown in Table 19.2. Table 19.3 (see appendix) is an example showing properties for soil/amendment mixtures useable in bioretention facilities.

Table 19.2 Infiltration rates and saturated hydraulic conductivities for amendment mixtures (Pitt, et al. 1999).

\begin{tabular}{lll}
\hline $\begin{array}{l}\text { Organic amendment } \\
\text { (\% of total mixture) }\end{array}$ & $\begin{array}{l}\text { Infiltration rate (in/h), assumed } \\
\text { to be slightly compacted }\end{array}$ & $\begin{array}{l}\text { Saturated hydraulic conductivity } \\
\text { (in/h) (same as infiltration rate) }\end{array}$ \\
\hline 10 & 1 & 1 \\
33 & 2.1 & 2.1 \\
50 & 2.5 & 2.5 \\
100 & 3.0 & 3.0 \\
\hline
\end{tabular}

Table 19.4 shows some crop coefficient factors (used to modify the reference $\mathrm{ET}_{\mathrm{o}}$ values), along with the root depths. Generally, deeper rooted plants are desired as they can remove water from deeper soil layers in the bioretention facility.

Table 19.4 Crop coefficient factors and root depths.

\begin{tabular}{lll}
\hline Plant & $\begin{array}{l}\text { Crop Coefficient Factor } \\
(\mathrm{Kc})\end{array}$ & $\begin{array}{l}\text { Root } \\
\text { (feet) }\end{array}$ \\
\hline Cool Season Grass (turfgrass) & 0.80 & 1 \\
Common Trees & 0.70 & 3 \\
Annuals & 0.65 & 1 \\
Common Shrubs & 0.50 & 2 \\
Warm Season Grass & 0.55 & 1 \\
Prairie Plants (deep rooted) & 0.50 & 6 \\
\hline
\end{tabular}

Reference monthly ET values are known for many areas of the country, but may not be readily available. As an example, Table 19.5 shows $\mathrm{ET}_{\mathrm{o}}$ values calculated by Kirby and Durrans (2006) for the Cahaba River Experimental Watershed in central Alabama determined as part of a climate change research project, while Table 19.6 shows $\mathrm{ET}_{\mathrm{o}}$ values for eighteen subareas in California, from the state agricultural extension research center. The reference $\mathrm{ET}_{0}$ values are usually given as average monthly rates, in./day. It is suggested that similar sources be investigated to obtain appropriate reference ET values for other areas. Many hydrology, water resources, and agricultural irrigation references outline the calculation methods that have been used to 
314 Evapotranspiration and Related Calculations for Bioretention Devices

determine these values. As an example Chin (2007) compares several approaches, including detailed examples, in his Water Resources Engineering book.

Table 19.5 Cahaba Experimental Watershed, Alabama, ETovalues (Kirby and Durrans, 2006).

\begin{tabular}{ll}
\hline Central Alabama & $\begin{array}{l}\text { Average daily (in/day) (irrigated } \\
\text { alfalfa reference conditions); } \mathrm{ET}_{\mathrm{o}}\end{array}$ \\
\hline January & 0.035 \\
February & 0.048 \\
March & 0.072 \\
April & 0.102 \\
May & 0.156 \\
June & 0.192 \\
July & 0.186 \\
August & 0.164 \\
September & 0.141 \\
October & 0.096 \\
November & 0.055 \\
December & 0.036 \\
\hline Total & 0.106 (annual average) \\
\hline
\end{tabular}

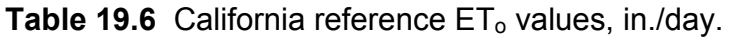

\begin{tabular}{lllllllllllll}
\hline $\begin{array}{l}\text { ETo } \\
\text { Zone }\end{array}$ & Jan & Feb & Mar & Apr & May & Jun & Jul & Aug & Sep & Oct & Nov & Dec \\
\hline 1 & 0.03 & 0.05 & 0.08 & 0.11 & 0.13 & 0.15 & 0.15 & 0.13 & 0.11 & 0.08 & 0.04 & 0.02 \\
2 & 0.04 & 0.06 & 0.10 & 0.13 & 0.15 & 0.17 & 0.16 & 0.15 & 0.13 & 0.09 & 0.06 & 0.04 \\
3 & 0.06 & 0.08 & 0.12 & 0.16 & 0.17 & 0.19 & 0.18 & 0.17 & 0.14 & 0.11 & 0.08 & 0.06 \\
4 & 0.06 & 0.08 & 0.11 & 0.15 & 0.17 & 0.19 & 0.19 & 0.18 & 0.15 & 0.11 & 0.08 & 0.06 \\
5 & 0.03 & 0.06 & 0.09 & 0.14 & 0.18 & 0.21 & 0.21 & 0.19 & 0.15 & 0.10 & 0.05 & 0.03 \\
6 & 0.06 & 0.08 & 0.11 & 0.16 & 0.18 & 0.21 & 0.21 & 0.20 & 0.16 & 0.12 & 0.08 & 0.06 \\
7 & 0.02 & 0.05 & 0.08 & 0.13 & 0.17 & 0.21 & 0.24 & 0.21 & 0.16 & 0.09 & 0.04 & 0.02 \\
8 & 0.04 & 0.06 & 0.11 & 0.16 & 0.20 & 0.23 & 0.24 & 0.21 & 0.17 & 0.11 & 0.06 & 0.03 \\
9 & 0.07 & 0.10 & 0.13 & 0.17 & 0.19 & 0.22 & 0.24 & 0.22 & 0.19 & 0.13 & 0.09 & 0.06 \\
10 & 0.03 & 0.06 & 0.10 & 0.15 & 0.19 & 0.24 & 0.26 & 0.23 & 0.17 & 0.10 & 0.05 & 0.03 \\
11 & 0.05 & 0.08 & 0.10 & 0.15 & 0.19 & 0.24 & 0.26 & 0.24 & 0.19 & 0.12 & 0.07 & 0.05 \\
12 & 0.04 & 0.07 & 0.11 & 0.17 & 0.22 & 0.26 & 0.26 & 0.23 & 0.18 & 0.12 & 0.06 & 0.03 \\
13 & 0.04 & 0.07 & 0.10 & 0.16 & 0.21 & 0.26 & 0.29 & 0.25 & 0.19 & 0.12 & 0.06 & 0.03 \\
14 & 0.05 & 0.08 & 0.12 & 0.17 & 0.22 & 0.26 & 0.28 & 0.25 & 0.19 & 0.13 & 0.07 & 0.05 \\
15 & 0.04 & 0.08 & 0.12 & 0.19 & 0.24 & 0.27 & 0.28 & 0.25 & 0.19 & 0.13 & 0.07 & 0.04 \\
16 & 0.05 & 0.09 & 0.13 & 0.19 & 0.25 & 0.29 & 0.30 & 0.27 & 0.21 & 0.14 & 0.08 & 0.05 \\
17 & 0.06 & 0.10 & 0.15 & 0.20 & 0.26 & 0.30 & 0.32 & 0.28 & 0.22 & 0.14 & 0.09 & 0.06 \\
18 & 0.08 & 0.12 & 0.17 & 0.23 & 0.28 & 0.32 & 0.31 & 0.28 & 0.23 & 0.16 & 0.10 & 0.07 \\
\hline
\end{tabular}

For Table 19.6: 
Reference: A Guide to Estimating Irrigation Water Needs of Landscape Plantings in California; The Landscape Coefficient Method and WUCOLS III. University of California Cooperative Extension. California Department of Water Resources.

http://www.owue.water.ca.gov/docs/wucols00.pdf (accessed May 28, 2006)

Zone 1: Coastal plains heavy fog belt. Lowest $\mathrm{ET}_{\mathrm{o}}$ in California, characterized by dense fog. (Santa Monica)

Zone 2: Coastal mixed fog area. Less fog and higher $\mathrm{ET}_{\mathrm{o}}$ than zone 1. (Santa Cruz)

Zone 3: Coastal valleys and plains and north coast mountains. More sunlight than zone 2. (Monterey/Salinas)

Zone 4: South coast inland plains and mountains north of San Francisco. More sunlight and higher summer $\mathrm{ET}_{\mathrm{o}}$ than zone 3. (San Diego)

Zone 5: Northern inland valleys. Valleys north of San Francisco. (Santa Rosa)

Zone 6: Upland central coast and Los Angeles basin. Higher elevation coastal areas. (Los Angeles)

Zone 7: Northeastern plains (Alturus)

Zone 8: Inland San Francisco bay area. Inland area near San Francisco with some marine influence. (San Jose)

Zone 9: South coast marine to desert transition. Inland area between marine and desert climates. (San Bernardino and Pasadena)

Zone 10: North central plateau and central coast range. Cool, high elevation areas with strong summer sunlight. Zone has limited climatic data and the zone selection is somewhat subjective. (Paicines)

Zone 11: Central Sierra Nevada. Mountain valleys east of Sacramento with some influence from delta breeze in summer. (Sonora)

Zone 12: East side Sacramento-San Joaquin Valley. Low winter and high summer ETo with slightly lower $\mathrm{ET}_{\mathrm{o}}$ than zone 14. (Fresno)

Zone 13: Northern Sierra Nevada. Northern Sierra Nevada mountain valleys with less marine influence than zone 11. (Quincy)

Zone 14: Mid-central valley, southern Sierra Nevada, Tehachapi and high desert mountains. High summer sunshine and wind in some locations. (Sacramento)

Zone 15: Northern and southern San Joaquin Valley. Slightly lower winter ETo due to fog and slightly higher summer ETo than zones 12 and 14. (Bakersfield)

Zone 16: West side San Joaquin Valley and mountains east and west of Imperial Valley. (Needles)

Zone 17: High desert valleys. Valleys in the high desert near Nevada and Arizona. (Needles)

Zone 18: Imperial Valley, Death Valley and Palo Verde. Low desert areas and high sunlight and considerable heat advection. (Palm Springs)

\subsection{Example Moisture Calculations}

This section contains several examples showing the water losses to be expected by bioretention facilities located in Birmingham, AL, contrasted to a similar facility located in Bakersfield, CA. An example calculation is also shown for a green roof in Los Angeles, CA. 19.3.1 Example Calculation for Birmingham, AL, Bioretention Facility 
Assume the following conditions and preliminary calculations:

Paved area draining to bioretention facility:

- 1.0 acre paved parking lot (assume an $\mathrm{Rv}$ of 0.85 , e.g. $85 \%$ of the rainfall volume occurs as runoff volume, for this calculation)

- 7.5 days until the start of the next rain (which is 0.47 in. in depth, lasting for $2.6 \mathrm{~h}$ ):

- 7.5 days $\times 24 \mathrm{~h} /$ day $=180 \mathrm{~h}$

- 47 in. $x 1.0$ acre $\times 0.85 \times \mathrm{ft} / 12$ in $\times 43,560 \mathrm{ft}^{2} /$ acre $=1,450$ $\mathrm{ft}^{3}$ of runoff expected

- Average runoff rate. Pitt (1987) found that the runoff duration is approximately 1.2 times the rain duration for small and intermediate-sized storms in urban areas. Therefore, the runoff duration $=1.2 \times 2.6 \mathrm{~h}=3.1 \mathrm{~h}$. The average runoff rate is therefore the total runoff volume divided by this runoff duration: $1,450 \mathrm{ft}^{3} / 3.1 \mathrm{~h}=465 \mathrm{ft}^{3} / \mathrm{h}$. This is the same as $0.13 \mathrm{ft}^{3} / \mathrm{sec}$, or $52 \mathrm{gal} / \mathrm{min}$

- Peak runoff rate. Pitt (1987) found that the peak runoff rate is approximately 3.8 times the average runoff rate for small and intermediate-sized storms in urban areas. The peak runoff rate is therefore estimated to be: $3.8 \times 465 \mathrm{ft}^{3} / \mathrm{h}=1,770 \mathrm{ft}^{3} / \mathrm{h}$. This is the same as $0.49 \mathrm{ft}^{3} / \mathrm{sec}$, or $198 \mathrm{gal} / \mathrm{min}$.

- Reference $\mathrm{ET}_{0}$; September in Birmingham, $\mathrm{AL}$ (0.141 in. per day $\mathrm{ET}_{\mathrm{o}}$ )

Bioretention facility:

- The bioretention facility is $1,000 \mathrm{ft}^{2}$ in area, or $2.3 \%$ of the paved surface area contributing flow to the bioretention device. In this example, this area, with a $2 \mathrm{ft}$ depression, has an adequate surface storage volume to capture the complete storm runoff volume of $1,450 \mathrm{ft}^{3}$, allowing all of the runoff to infiltrate with time. Table 19.7 (see appendix) estimates that the infiltration rate is about $1.7 \mathrm{in} / \mathrm{h}$ for this device. This corresponds to about $140 \mathrm{ft}^{3} / \mathrm{h}$ infiltration rate capacity for this bioretention device $\left(1,000 \mathrm{ft}^{2} \times 1.7\right.$ $\mathrm{in} / \mathrm{h} \mathrm{x} \mathrm{ft} / 12 \mathrm{in}=140 \mathrm{ft}^{3} / \mathrm{h}$ ). It would therefore require about $10 \mathrm{~h}$ to completely infiltrate the water from this runoff event $\left(1,450 \mathrm{ft}^{3} / 140\right.$ $\mathrm{ft}^{3} / \mathrm{h}=10.3 \mathrm{~h}$ ).

Current soil moisture level in biofilter engineered soil layer: 37\% 
- Engineered soil: 36 in. of sandy loam amended with $25 \%$ peat (Table 19.7 summarizes the soil moisture capacities and infiltration rates for this soil mixture)

- Bioretention facility plants: Half common shrubs (Kc crop coefficient factor of 0.50 and $2 \mathrm{ft}$ root depth) and half annuals (Kc 0.64 and $1 \mathrm{ft}$ root depth)

\section{Calculation Outline}

1. How much water is trapped in the engineered soil layer? It is reasonable to assume that the initial starting soil water level is at field capacity, as the gravity drainage time is relatively rapid for most engineered soils (a suggested "default" condition), or it can be set for any other starting condition specified by the user, as in this example.

- The starting moisture condition for this example is $37 \%$ moisture in the amended engineered soil layer, intermediate between the field capacity (29\%) and saturation (50\%). Therefore, for the 36 in. thick engineered soil layer, there is $0.37 \times 36$ in. $=13.3 \mathrm{in}$. of water in the 3 $\mathrm{ft}$ engineered soil layer (or $4.44 \mathrm{in}$. of water per foot depth of soil). Over the $1,000 \mathrm{ft}^{2}$ bioretention area, this is equal to about $1,110 \mathrm{ft}^{3}$ for the $3 \mathrm{ft}$ thickness, or about $370 \mathrm{ft}^{3}$ of water in each foot of depth of the engineered soil.

2. How much water will drain by gravity before the next rain? If moisture level > field capacity, the soil will drain according to the saturated hydraulic conductivity rate $(\mathrm{Ks})$ to the underlying storage layer. The vertical drainage rate is equal to the porosity times the Ks rate, until field capacity is reached (need to also determine hours needed to drain to field capacity). The amount of soil water above the field capacity that is susceptible to gravity drainage, and the associated drainage time, is calculated below:

- Excess over field capacity (gravity draining soil water): the field capacity is $29 \%$ (limit of gravity drainage) but there is $37 \%$ water content for the starting conditions. Therefore, have $8 \%$, or 0.08 in. of water per inch of soil ( 0.96 in. of water per foot of soil, or 2.88 in. of soil water for the $3 \mathrm{ft}$ thickness of the engineered soil), that will gravity drain at the saturated hydraulic conductivity rate $(\mathrm{Ks}=$ $1.7 \mathrm{in} / \mathrm{h}$ in this example). Therefore, it is expected that this will drain down to field capacity in $2.88 \mathrm{in} . / 1.7 \mathrm{in} / \mathrm{h}=1.7 \mathrm{~h}$. (assuming $\mathrm{i}$ is 1 as in the Darcy equation, typical for vertical drainage). This assumes that there is sufficient storage capacity in the underlying 
storage layer and/or the subsurface seepage rate can also keep up with loss rate. Therefore, for this condition, this excess water over field capacity will likely be gone before significant ET losses occur, but the following calculations for ET are also made. This excess over field capacity that can gravity drain amounts to:

(initial moisture field capacity) $x$ depth of engineered soil, inches $x$ $\frac{f t}{12 \text { in }} x$ area of biofilter, square feet $=$ drainage water volume, $f t^{3}$

Substituting values for this example:

$$
(0.37-0.29) \times 36 \text { in } \times \frac{f t}{12 \text { in }} \times 1,000 f^{2}=240 f t^{3}
$$

or about $80 \mathrm{ft}^{3}$ of water per foot of engineered soil.

3. ET loss until start of next rain. ET only occurs in the root zones of the plants and only affects the soil water between the field capacity and permanent wilting point levels.

- There are 7.5 days (all in September) until the next rain. The reference $\mathrm{ET}_{\mathrm{o}}$ loss rate is 0.141 in/day for this period. The maximum soil moisture loss rate due to $\mathrm{ET}_{\mathrm{o}}$ before the rain is therefore 7.5 days $\mathrm{X} 0.141 \mathrm{in} /$ day $=1.06 \mathrm{in}$. of soil water. For the $1,000 \mathrm{ft}^{2}$ area, this maximum would be about $88 \mathrm{ft}^{3}$ of soil water loss due to ET, or about $29 \mathrm{ft}^{3}$ for each foot thickness of engineered soil, assuming it is evenly distributed vertically. However, the bioretention facility surface is planted half in shrubs and half in annuals. The Kc crop coefficient for the shrubs is 0.5 ( $2 \mathrm{ft}$ root depth) and the $\mathrm{Kc}$ for the annuals is 0.65 ( $1 \mathrm{ft}$ root depth).

For the top foot of the engineered soil, the actual ET loss rate is the average of these two (since equal areas of each type are planted): 0.58 weighted $\mathrm{Kc}$, for an actual loss rate of $0.58 \times 29 \mathrm{ft}^{3}=17 \mathrm{ft}^{3}$.

- For the 1 to $2 \mathrm{ft}$ layer, only the shrubs affect the moisture, so the actual ET losses are half of the shrub rate (since they are only planted over half of the area), for a 0.25 weighted $\mathrm{Kc}$, for an actual loss rate of $0.25 \times 29 \mathrm{ft}^{3}=7.3 \mathrm{ft}^{3}$. 
4. Determine moisture level at start of next rain, and the moisture deficit to saturated conditions. The above information is organized in Table 19.8 (divided into one foot increments for the engineered soil, because of the different plants having different root depths).

Table 19.8 Soil water content by soil layers in Birmingham Example.

\begin{tabular}{|c|c|c|c|c|c|}
\hline $\begin{array}{l}\text { Engineered } \\
\text { soil layer }\end{array}$ & $\begin{array}{l}\text { Initial } \\
\text { conditions ( } \mathrm{ft}^{3} \\
\text { of water) } 37 \% \\
\text { moisture }\end{array}$ & $\begin{array}{l}\text { Losses from } \\
\text { gravity } \\
\text { drainage }\left(\mathrm{ft}^{3}\right. \\
\text { of water) }\end{array}$ & $\begin{array}{l}\text { Losses from } \\
\text { shrubs and } \\
\text { annuals ET } \\
\left(\mathrm{ft}^{3} \text { of }\right. \\
\text { water })\end{array}$ & $\begin{array}{l}\text { Final } \\
\text { conditions at } \\
\text { start of next } \\
\text { rain }\left(\mathrm{ft}^{3} \text { of }\right. \\
\text { water over } \\
1,000 \mathrm{ft}^{2} \\
\text { biofilter area) }\end{array}$ & $\begin{array}{l}\text { Deficit to } \\
\text { saturated } \\
\text { conditions } \\
\left(\mathrm{ft}^{3} \text { of }\right. \\
\text { water })^{*}\end{array}$ \\
\hline Top foot & 370 & 80 & 17 & $\begin{array}{l}273 \quad(27.3 \% \\
\text { moisture**) }\end{array}$ & 227 \\
\hline 1 to 2 foot & 370 & 80 & 7.3 & $\begin{array}{l}282.7(28.3 \% \\
\text { moisture })\end{array}$ & 217.3 \\
\hline 2 to 3 foot & 370 & 80 & 0 & $\begin{array}{l}290 \quad(29 \% \\
\text { moisture, the } \\
\text { field capacity } \\
\text { since there are } \\
\text { no roots in this } \\
\text { zone) }\end{array}$ & 210 \\
\hline $\begin{array}{l}\text { Total in } 3 \mathrm{ft} \text { of } \\
\text { engineered soil }\end{array}$ & 1,100 & 240 & 24.3 & $\begin{array}{l}845.7 \quad(28.2 \% \\
\text { moisture) No } \\
\text { irrigation } \\
\text { needed, as } \\
\text { much greater } \\
\text { than the } \\
\text { wilting point } \\
\text { of } 6.1 \% \text {. }\end{array}$ & 654.3 \\
\hline
\end{tabular}

* Saturated conditions correspond to $500 \mathrm{ft}^{3}$ of water per foot of depth for this site, as the saturated water capacity is equal to the porosity which is $50 \%$. Each foot depth of the engineered soil in the $1,000 \mathrm{ft}^{2}$ bioretention device has $1,000 \mathrm{ft}^{3}$ of soil, and $500 \mathrm{ft}^{3}$ of pores that can fill with water at saturation.

** Each foot of the 1,000 $\mathrm{ft}^{2}$ bioretention device has $1,000 \mathrm{ft}^{3}$ of soil. Therefore, $273 \mathrm{ft}^{3}$ of soil water represents $100(273 / 1,000)=27.3 \%$ moisture levels. The three feet thickness has $3,000 \mathrm{ft}^{3}$ of soil, so the $845.7 \mathrm{ft}^{3}$ of soil water represents $28.2 \%$ moisture.

No irrigation was needed for this example interevent period and ET. If no peat amendment was added to the sandy loam soil, the field capacity would be less (about 20\%, compared the $29 \%$ for the mixture), and the wilting point would be slightly higher (about $6.5 \%$, compared to about $6.1 \%$ for the mixture). The available soil moisture for the plants was therefore about $23 \%$ for the amended soil mixture, compared to about $13 \%$ for the sandy loam 
soil alone. Although the ET was relatively small for this example, there may be some conditions where the extra available soil moisture supplied by an organic supplement may be important (such as extended dry periods in arid locations of the country). Automatic irrigation systems should be considered to save the plants if the modeling indicates critical conditions may be reached for the biofilter design.

5. How much of the deficits will be satisfied by the rain event infiltrating water, and what will be the soil moisture level after the rain?

- The rain is expected to produce a total of $1,450 \mathrm{ft}^{3}$ of runoff.

- The field capacity to saturation capacity (gravity drainage amount) is 50 to $29 \%$ soil moisture; for the $1,000 \mathrm{ft}^{2}$ area and $3 \mathrm{ft}$ of engineered soil, this amounts to about $630 \mathrm{ft}^{3}$ of water.

- The field capacity to permanent wilting point is 29 to $6.1 \%$ soil moisture; for the $1,000 \mathrm{ft}^{2}$ area and $3 \mathrm{ft}$ of engineered soil, this amounts to about $690 \mathrm{ft}^{3}$ of water.

- The calculations above show that the actual deficit is $654.3 \mathrm{ft}^{3}$ to saturation conditions. The soil will therefore be saturated to $100 \%$ during the rain, as about $1,450 \mathrm{ft}^{3}$ of runoff will enter the bioretention device. The engineered soil will capture about $654.3 \mathrm{ft}^{3}$ of the runoff, leaving about $1,450-654.3 \mathrm{ft}^{3}=795.7 \mathrm{ft}^{3}$ to potentially pond on the surface to be slowly infiltrated at the saturated hydraulic conductivity (Ks) rate. Only $24.3 \mathrm{ft}^{3}$ of water will be retained in the engineered soil to make up for the slight deficit of the surface 2 feet of soil being below the field capacity level due to ET during the interevent period.

In this example, the Ks rate is the same as the infiltration rate for the engineered soil. The Ks rate of $1.7 \mathrm{in} / \mathrm{h}$. will drain the runoff through the biofilter over a period of about:

$$
1.7 \frac{i n}{h r} \times \frac{f t}{12 i n} \times 1,000 f t^{2}=141.7 \frac{f t^{3}}{h r}
$$

With a total runoff volume of $1,450 \mathrm{ft}^{3}$, minus the $24.3 \mathrm{ft}^{3}$ losses due to ET, the amount of runoff to be infiltrated through the bioretention device is $1,426 \mathrm{ft}^{3}$ which would enter the storage layer and the underdrains, if present, and surrounding soil. It would require about $10.1 \mathrm{~h}$ to infiltrate this water through the bioretention device and for the moisture levels to reach the field capacity moisture level in the engineered soil. 
6. Groundwater protection provided by this bioretention device?

The vertical velocity of the infiltrating water through the engineered soil is $\mathrm{Ks} /$ porosity $=1.7 \mathrm{in} / \mathrm{h} / 0.5=3.4 \mathrm{in} / \mathrm{h}$. With a 36 inch deep engineered soil, the contact time with the engineered soil is therefore $36 \mathrm{in} . / 3.4 \mathrm{in} / \mathrm{h}=10.6 \mathrm{~h}$. Shallower engineered soils would provide less contact time. This is a reasonable amount of time for the water to be in contact with the engineered soil, which has an appreciable CEC level ( $81 \mathrm{meq} / 100$ grams of soil), providing some groundwater protection. The next section describes the CEC calculations in more detail, but as a quick evaluation, the $3,000 \mathrm{ft}^{3}$ of engineered soil at 1.24 grams $/ \mathrm{cm}^{3}$ density and having $81 \mathrm{meq} / 100$ grams has a total CEC content of about:

$$
3,000 \mathrm{ft}^{3} \times \frac{\mathrm{m}^{3}}{36.0 \mathrm{ft}^{3}} \frac{1.24 \mathrm{~g}}{\mathrm{~cm}^{3}} \times \frac{(100 \mathrm{~cm})^{3}}{\mathrm{~m}^{3}} \times \frac{81 \mathrm{meq}}{100 \mathrm{~g}}=83,700,000 \mathrm{meq}
$$

With an example total major cation content of stormwater of $1 \mathrm{meq} / \mathrm{L}$, about 84 million L (33 million gallons, or 3 million $\mathrm{ft}^{3}$ ) of stormwater can be treated by this biofilter before the CEC of the engineered soil is exhausted. This may correspond to about 1,000 in. of rainfall for this example site of 1 acre of pavement. With 52 in. of rain per year, the expected life of the CEC capacity would therefore be about 15 to $20 \mathrm{y}$. Without adding the peat amendment to the sandy loam soil, the CEC would only be about 0.1 of this amount, with a very short useful life of just a few years.

7. Clogging of bioretention device

Excessive loading of particulates on bioretention devices could have significant detrimental effects on their treatment rates. Media filtration tests indicate critical loadings of about 5 to $25 \mathrm{~kg} / \mathrm{m}^{2}$ of particulate solids. Assuming a particulate solids concentration of $50 \mathrm{mg} / \mathrm{L}$ for this site, a 1.0 acre paved parking lot $\left(\mathrm{R}_{\mathrm{v}}=0.85\right)$, in an area receiving 52 in. of rain per year:

(50 mg SS/L) (kg/1,000,000 mg) (0.85) (52 in/y) (ft/12 in) (1 acre) $(43,560$ $\mathrm{ft}^{2} /$ acre $)\left(28.3 \mathrm{~L} / \mathrm{ft}^{3}\right)=227 \mathrm{~kg} / \mathrm{y}$. for this site

With a surface area of $1,000 \mathrm{ft}^{2}\left(92 \mathrm{~m}^{2}\right)$, this corresponds to an annual particulate solids loading of about $2.5 \mathrm{~kg} / \mathrm{m}^{2}$ per year. About $10 \mathrm{y}$. would be needed to reach a critical loading of $25 \mathrm{~kg} / \mathrm{m}^{2}$. Because of the relatively slow loading rate and the extensive use of plants, the site is likely to be useful for a much longer period. Additional protection can be provided by ensuring 
that a setting chamber is used at the biofilter inlets, or grass swales are used to filter the runoff before reaching the infiltration device.

Another clogging issue is the soil and runoff SAR conditions, as discussed in a later section. With elevated soil SAR values, clays can be become unstabilized, leading to premature clogging. This is especially important in areas where salts are used for de-icing controls. The high sodium levels in the seasonal runoff can elevate the SAR to critical values, with additional time needed to leach the sodium from the soils. Of course, this may provide some advantages of reducing infiltration during snowmelt periods when groundwater contamination by chlorides is critical. Adding gypsum to the soil will reduce the SAR. The supplemental spreadsheet can be used to predict SAR potential problems for a biofiltration site.

\subsubsection{Example Calculation for Bakersfield, CA, Bioretention Device}

A short example is provided here for the same conditions as described above, except the interevent period before the next rain is 75 days and the months are June and July. Under these conditions, the ET is expected to much more important than in the previous example. The reference $\mathrm{ET}_{\mathrm{o}}$ value for June and July in Bakersfield, California, is assumed to be 0.28 in/day for this example.

ET loss until start of next rain. ET only occurs in the root zones of the plants and only affects the soil water between the field capacity and permanent wilting point levels.

- There are 75 days (all in June and July) until the next rain. The reference $\mathrm{ET}_{\mathrm{o}}$ loss rate is about $0.28 \mathrm{in} /$ day for this period. The maximum soil moisture loss rate due to $\mathrm{ET}_{\mathrm{o}}$ before the rain is therefore 75 days X 0.28 in/day $=21$ in. of soil water. For the 1,000 $\mathrm{ft}^{2}$ area, this maximum would be about $1,750 \mathrm{ft}^{3}$ of soil water loss due to ET, or about $583 \mathrm{ft}^{3}$ for each foot of engineered soil, assuming it is evenly distributed vertically. However, the biofilter surface is planted half in shrubs and half in annuals. The Kc crop coefficient for the shrubs is 0.5 ( $2 \mathrm{ft}$ root depth) and the $\mathrm{Kc}$ for the annuals is 0.65 (1 ft root depth).

- For the top foot of the engineered soil, the actual ET loss rate is the average of these two (since equal areas of each type are planted): 0.58 weighted Kc, for an actual loss rate of $0.58 \times 583 \mathrm{ft}^{3}=338 \mathrm{ft}^{3}$. 
- For the 1 to $2 \mathrm{ft}$ layer, only the shrubs affect the moisture, so the actual ET losses are half of the shrub rate (since they are only planted over half of the area), for a 0.25 weighted Kc, for an actual loss rate of $0.25 \times 583 \mathrm{ft}^{3}=146 \mathrm{ft}^{3}$.

The above information is organized in Table 19.9 (divided into one foot increments for the engineered soil, because of the different plants having different root depths).

Table 19.9 Water conditions in Bakersfield, CA, bioretention facility.

\begin{tabular}{|c|c|c|c|c|c|}
\hline $\begin{array}{l}\text { Engineered } \\
\text { soil layer }\end{array}$ & $\begin{array}{l}\text { Initial } \\
\text { conditions }\left(\mathrm{ft}^{3}\right. \\
\text { of water) } 37 \% \\
\text { moisture }\end{array}$ & $\begin{array}{l}\text { Losses from } \\
\text { gravity } \\
\text { drainage }\left(\mathrm{ft}^{3}\right. \\
\text { of water) }\end{array}$ & $\begin{array}{l}\text { Losses from } \\
\text { shrubs and } \\
\text { annuals ET } \\
\left(\mathrm{ft}^{3} \text { of water) }\right.\end{array}$ & $\begin{array}{l}\text { Final } \\
\text { conditions at } \\
\text { start of next } \\
\text { rain }\left(\mathrm{ft}^{3} \text { of }\right. \\
\text { water over } \\
1,000 \quad \mathrm{ft}^{2} \\
\text { biofilter area) }\end{array}$ & $\begin{array}{l}\text { Deficit to } \\
\text { saturated } \\
\text { conditions } \\
\left(\mathrm{ft}^{3} \text { of water) }\right.\end{array}$ \\
\hline Top foot & 370 & 80 & $\begin{array}{l}338 \text { (stops at } \\
229 \text { when } \\
\text { wilting point } \\
\text { is reached) }\end{array}$ & $\begin{array}{l}-48 \text { (Can't be } \\
\text { below } 61 \mathrm{ft}^{3} \text {, } \\
\text { as that is the } \\
\text { wilting point } \\
\text { at } 6.1 \% \text { ) }\end{array}$ & 439 \\
\hline 1 to 2 foot & 370 & 80 & 146 & $\begin{array}{l}144 \quad(14.4 \% \\
\text { moisture })\end{array}$ & 356 \\
\hline 2 to 3 foot & 370 & 80 & 0 & $\begin{array}{l}290 \quad(29 \% \\
\text { moisture, the } \\
\text { field capacity } \\
\text { since there } \\
\text { are no roots } \\
\text { in this zone) }\end{array}$ & 210 \\
\hline $\begin{array}{l}\text { Total in } 3 \mathrm{ft} \text { of } \\
\text { engineered soil }\end{array}$ & 1,100 & 240 & 375 & $\begin{array}{l}495 \quad(16.5 \% \\
\text { moisture }) . \\
\text { Irrigation } \\
\text { needed in top } \\
\text { foot to } \\
\text { prevent } \\
\text { wilting point } \\
\text { of } 6.1 \% \text {. }\end{array}$ & 1,005 \\
\hline
\end{tabular}

It is necessary to add at least $109 \mathrm{ft}^{3}\left(48+61 \mathrm{ft}^{3}\right)$ of water in the top foot to keep the soil moisture level right at the wilting point before the next rain. If no peat amendment was added to the sandy loam soil, the field capacity would be less (about 20\%, compared the $29 \%$ for the mixture), and the wilting point would be slightly higher (about $6.5 \%$, compared to about $6.1 \%$ 
for the mixture). The available soil moisture for the plants was therefore about $23 \%$ for the amended soil mixture, compared to about $13 \%$ for the sandy loam soil alone. Much more supplemental irrigation water would be needed without the added organic supplement that can hold large amounts of water after gravity drainage.

Automatic irrigation systems should be considered to save the plants if the modeling indicates critical conditions may be reached for the bioretention device design, such as in this example. It is suggested that irrigation be automatically started above the wilting point at about $25 \%$ of the available soil moisture content (at about $0.25 \times 23 \%+6.1 \%=12 \%$ soil moisture for this example), and turned off when about $85 \%$ of the available soil moisture content is reached (at about $0.85 \times 23 \%+6.1 \%=26 \%$ soil moisture). In this example, the top foot would need supplemental irrigation, while the 1 to 2 foot layer, and the 2 to $3 \mathrm{ft}$ deep layer, would not. This $14 \%$ soil moisture increase in the top foot corresponds to about $140 \mathrm{ft}^{3}$ of irrigation water for this example. This is greater than the minimum $109 \mathrm{ft}^{3}$ that would be needed to barely meet the wilting point before the rain. This is a small amount of extra water that would keep the soil above the wilting point before the rain (at least at $12 \%$ in the top foot). This would slightly decrease the deficit to saturation conditions also. Irrigation would therefore save the plants, providing ET after they would otherwise die off, at a minimum effect on the overall water balance.

\subsubsection{Example ET and Drainage Calculation for Los Angeles, CA Green Roof}

The following example is for a green roof located in Los Angeles, California, that is $5,000 \mathrm{ft}^{2}$ in area. The roof has a $4 \%$ slope and is about $70 \mathrm{ft}$ on each side. The roof has a light-weight gravel-sized drainage layer that is 3 in. thick over an impervious membrane. The growing substrate is a light-weight vermiculate/peat mixture (50/50) and is 6 in. thick. The plants are a warm season grass ( $\mathrm{Kc}$ crop coefficient factor of 0.55 , with a maximum root depth of $1 \mathrm{ft}$, here restricted to the 6 in. growing substrate). The example dry period is 30 days long (May) and the rain is 0.23 in. in depth, lasting $5 \mathrm{~h}$. Table 19.10 (see appendix) shows the characteristics of the green roof media for this example.

1. Determine the drainage time in the drain layer. 
$\mathrm{Ks}$ is $500 \mathrm{in} / \mathrm{hr}$ for coarse sand/gravel-sized drainage layer, the roof slope, i, is $4 \%$, or 0.04 , and the cross-sectional area of the drain is $70 \mathrm{ft}$ by $0.25 \mathrm{ft}$. The drainage rate is therefore: $500 \mathrm{in} / \mathrm{h} . \mathrm{X}$ in/ $12 \mathrm{ft} X 0.04 \times 70 \mathrm{ft} X 0.25 \mathrm{ft}=$ $29.2 \mathrm{ft}^{3} / \mathrm{h}$.

- The rainfall quantity is: 0.23 in $\mathrm{X} \mathrm{ft} / 12$ in $\mathrm{X} 5,000 \mathrm{ft}^{2}=96 \mathrm{ft}^{3}$

- The rain rate $(0.23 \mathrm{in} / 5 \mathrm{~h}$. $=0.046 \mathrm{in} / \mathrm{h}$. $)$ is $96 \mathrm{ft}^{3} / 5 \mathrm{~h}$. $=19.2 \mathrm{ft}^{3} / \mathrm{h}$. The peak rain intensity may be about 3.8 times this amount, or about $(0.17$ in $/ \mathrm{h}$.) $73 \mathrm{ft}^{3} / \mathrm{h}$.

- The total storage volumes of these media at saturation, at field capacity, and at permanent wilting points, are about:

Total Moisture Content at Saturation:

Drainage layer: $5,000 \mathrm{ft}^{2} \times 0.25 \mathrm{ft} X 0.32=400 \mathrm{ft}^{3}$ total pore volume Growing media: $5,000 \mathrm{ft}^{2}$ X $0.5 \mathrm{ft}$ X $0.64=1,600 \mathrm{ft}^{3}$ total pore volume Total: $2,000 \mathrm{ft}^{3}$ total pore volume

Moisture Content at Field Capacity:

Drainage layer: $5,000 \mathrm{ft}^{2}$ X $0.25 \mathrm{ft}$ X $0.04=50 \mathrm{ft}^{3}$ field capacity Growing media: $5,000 \mathrm{ft}^{2}$ X $0.5 \mathrm{ft}$ X $0.50=1,250 \mathrm{ft}^{3}$ field capacity Total: $1,300 \mathrm{ft}^{3}$ field capacity

Moisture Content at Permanent Wilting Point:

Drainage layer: $5,000 \mathrm{ft}^{2} \times 0.25 \mathrm{ft} \times 0.00=0 \mathrm{ft}^{3}$ at wilting point Growing media: $5,000 \mathrm{ft}^{2} \times 0.5 \mathrm{ft} \times 0.05=125 \mathrm{ft}^{3}$ at wilting point Total: $125 \mathrm{ft}^{3}$ at wilting point

Therefore, the water storage volume susceptible to gravity drainage (between the saturation and field capacity) is:

Drainage layer: $400-50 \mathrm{ft}^{3}=350 \mathrm{ft}^{3}$

Growing media: $1600-1250 \mathrm{ft}^{3}=350 \mathrm{ft}^{3}$

Total: $700 \mathrm{ft}^{3}$ storage susceptible to gravity drainage

The total available water content for the plants (between the field capacity and permanent wilting point) is:

Drainage layer: $50-0 \mathrm{ft}^{3}=50 \mathrm{ft}^{3}$ (ignore, as the roots are restricted to the top 6 in.)

Growing media: $1250-125 \mathrm{ft}^{3}=1,125 \mathrm{ft}^{3}$

Total: 1,175 $\mathrm{ft}^{3}$ storage available for plants (ET consumption), but only use the amount in the 6 in. of growing media $\left(1,125 \mathrm{ft}^{3}\right)$ 
- The amount of storage between the field capacity and saturation levels, susceptible to gravity drainage, is about $700 \mathrm{ft}^{3}$, corresponding to about 1.7 in. of rain.

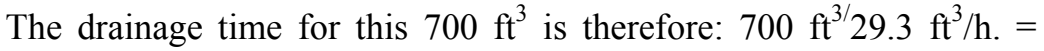
$23.9 \mathrm{~h}$. (the roof slope was set to $4 \%$ in order to provide a drainage time of about $24 \mathrm{~h} .$. , a typical requirement. Other options, including the use of a more efficient drainage media, could also have been used instead of using this relative steep "flat" roof).

- The infiltration rate for the growing media $(2.5 \mathrm{in} / \mathrm{h})$ is very high compared to most rainfalls and should allow most of the rain to enter the media. The storage likely available in the media and growing layers is also quite large and can accommodate most rains before the drainage system carries the water to the roofdrains.

The growing media itself has about $350 \mathrm{ft}^{3}$ of available storage between saturation and field capacity. With a drainage rate of $29.3 \mathrm{ft}^{3} / \mathrm{h}$, it would require about $12 \mathrm{~h}$. to drain this layer.

2. Determine the ET before the next rain event.

The reference $\mathrm{ET}_{\mathrm{o}}$ for the site (Los Angeles in May) is about $0.18 \mathrm{in} /$ day. The plants are a warm season grass, with a crop coefficient factor $(\mathrm{Kc})$ of 0.55 , with a maximum root depth restricted to the 6 in. growing media.

- For a 30 day growing period, the ET consumption for the roof plants are: 0.18 in/day X 30 days $X 0.55=2.97$ in.

For the 5,000 $\mathrm{ft}^{2}$ roof, this totals: 2.97 in X ft/12 in $\mathrm{X} 5,000 \mathrm{ft}^{2}=1,238$ $\mathrm{ft}^{3}\left(41.3 \mathrm{ft}^{3}\right.$ /day) which is more than the $1,125 \mathrm{ft}^{3}$ available in the growing media. With a wilting point of $5 \%$ in the growing media, the maximum available moisture is $1,125 \mathrm{ft}^{3}$, which would be met after about 27 days under the May growing conditions.

Irrigation would therefore be needed to ensure survivability of the plants. The irrigation system should automatically turn on when the moisture level approaches $25 \%$ of the available moisture level between the field capacity and permanent wilting point $(50 \%-5 \%=$ $45 \%$ ). This would be the $0.25 \times 45 \%+5 \%=16 \%$ moisture level (the lowest allowable moisture level in the growing media). The irrigation system should automatically turn off when the moisture level approaches about $85 \%$ of the available moisture level between the 
field capacity and permanent wilting point $(50 \%-5 \%=45 \%)$. This would be the $0.85 \times 45 \%+5 \%=43 \%$ moisture level.

The amount of water to be irrigated at this level would therefore be: $(0.43-0.16) \times 0.5 \mathrm{ft} \times 5,000 \mathrm{ft}^{2}=675 \mathrm{ft}^{3}$ of water. This is a substantial amount of water and would correspond to a rain depth of about $1.6 \mathrm{in}$. Therefore, this is a poor plant selection for this site. The warm season grass should be replaced by a plant that can tolerate periods of very dry conditions, and have a much lower crop coefficient factor.

3. Determine the moisture content of the green roof media at the start and end of the next rain event.

The 0.23 in. rain depth is only $100(0.23 / 6)=3.8 \%$ water in the 6 in. of media. Assuming the growing media is at the permanent wilting point $(5.0 \%$ moisture), the moisture level in the media after the rain would only be $8.8 \%$. The 0.23 in. rain would only add $96 \mathrm{ft}^{3}$ of water to the green roof. The warm season grass on this $5,000 \mathrm{ft}^{2}$ roof consumes $41.3 \mathrm{ft}^{3} /$ day through ET losses. This rain would therefore only satisfy this grass for about 2.3 days. This grass therefore needs about $0.1 \mathrm{in}$. of rain per day to make up for the ET losses for May in Los Angeles, again stressing the need to use another plant for this green roof.

\subsection{Descriptions of Supplemental Calculations using the CEC/SAR and Loading Spreadsheet}

The following paragraphs describe the calculations performed by the supplemental spreadsheet that determines the approximate clogging conditions, CEC life capacity of bioretention media, and potential SAR problems associated with the water and soil chemistry. This spreadsheet is available at:

http://unix.eng.ua.edu/ rpitt/SLAMMDETPOND/MainSLAMMDETPOND.html

(Loading and Treatment Needs Spreadsheet in the left download column).

Since these are only approximate estimates for these problems, relatively simplistic approaches in calculating runoff volume and sediment characteristics are used. These are only intended to indicate the relative magnitude of the problem associated with these major issues in the operation of a bioretention device. 


\subsubsection{Clogging Calculations}

Bioretention designs can be based on the predicted annual discharge of suspended solids to the biofiltration device and the desired media replacement interval. Infiltration and bioretention devices may start to show significantly reduced infiltration capacities after about 1 to $5 \mathrm{lb} / \mathrm{ft}^{2}$ (5 to $25 \mathrm{~kg} / \mathrm{m}^{2}$ ) of particulate solids have been loaded (Clark 1996, 2000; Urbonas 1996). Deeply-rooted vegetation and a healthy soil structure can extend the actual life much longer; however abuse (especially compaction and excessive siltation) can significantly reduce it. The volumetric runoff coefficients $\left(\mathrm{R}_{\mathrm{v}}\right.$, the volumetric fraction of that rainfall that occurs as runoff) (Table 19.11) can be used to approximate the fraction of annual rainfall that would occur as runoff for various land uses and surface conditions.

Table 19.11 Volumetric runoff coefficients by land use

\begin{tabular}{ll}
\hline Area & $\begin{array}{l}\text { Volumetric Runoff } \\
\text { Coefficient (Rv) }\end{array}$ \\
\hline Low density residential land use & 0.15 \\
Medium density residential land use & 0.3 \\
High density residential land use & 0.5 \\
Commercial land use & 0.8 \\
Industrial land use & 0.6 \\
Paved areas & 0.85 \\
Sandy soils & 0.1 \\
Clayey soils & 0.3 \\
\hline
\end{tabular}

Table 19.12 summarizes likely suspended solids concentrations associated with different urban areas and waters (Pitt, et al. 2005a and 2005b).

Table 19.12 Suspended solids concentration by land use.

\begin{tabular}{ll}
\hline Source Area & $\begin{array}{l}\text { Suspended Solids } \\
\text { Concentration }(\mathrm{mg} / \mathrm{L})\end{array}$ \\
\hline Roof runoff & 10 \\
Paved parking, storage, driveway, streets, and walk areas & 50 \\
Unpaved parking and storage areas & 250 \\
Landscaped areas & 500 \\
Construction site runoff & 10,000 \\
Combined sewer overflows & 100 \\
Detention pond water & 20 \\
Mixed stormwater & 150 \\
Effluent after high level of pretreatment of stormwater & 5 \\
\hline
\end{tabular}


Using this information and the local annual rain depth and source area size, it is possible to estimate the annual suspended solids loading from an area and to determine clogging potential for a bioretention device. The following three examples illustrate these simple calculations:

\section{Example 1}

A 1.0 ha paved parking lot $\left(\mathrm{R}_{\mathrm{v}}=0.85\right)$, in an area receiving $1.0 \mathrm{~m}(3.3 \mathrm{ft})$ of rain per year:

$(50 \mathrm{mg} \mathrm{SS} / \mathrm{L})(0.85)(1 \mathrm{~m} / \mathrm{y})(1 \mathrm{ha})\left(10,000 \mathrm{~m}^{2} / \mathrm{ha}\right)\left(1,000 \mathrm{~L} / \mathrm{m}^{3}\right)(\mathrm{g} / 1,000$ $\mathrm{mg})$

$=425,000 \mathrm{~g} \mathrm{SS} / \mathrm{y}$

Therefore, if a bioretention device is to be used having an expected suspended solids capacity of $15 \mathrm{~kg} / \mathrm{m}^{2}\left(3 \mathrm{lb} / \mathrm{ft}^{2}\right)$ before "clogging," then $28 \mathrm{~m}^{2}\left(300 \mathrm{ft}^{2}\right)$ of this bioretention device will be needed for each year of desired operation for this 1.0 ha $(2.5$ acre $)$ site. This is about $0.3 \%$ of the paved area per year of operation, so if $10 \mathrm{y}$. were desired before the media needed to be exchanged, an area of about $3 \%$ of the contributing area would be needed for the bioretention device. If this water was pretreated to a high level so the effluent has a much reduced concentration of particulates (to about $5 \mathrm{mg} / \mathrm{L}$ suspended solids), then only about $0.03 \%$ of the contributing paved area would be needed for the bioretention area each year of operation.

\section{Example 2}

A 100 ha medium density residential area $\left(\mathrm{R}_{\mathrm{V}}=0.3\right), 1.0 \mathrm{~m}$ of rain per year: $(150 \mathrm{mg} \mathrm{SS} / \mathrm{L})(0.3)(1 \mathrm{~m} / \mathrm{y})(100 \mathrm{ha})\left(10,000 \mathrm{~m}^{2} / \mathrm{ha}\right)\left(1,000 \mathrm{~L} / \mathrm{m}^{3}\right)(\mathrm{g} / 1,000$ $\mathrm{mg})$

$=45,000,000 \mathrm{~g} \mathrm{SS} / \mathrm{y}$

The unit area loading of suspended solids for this residential area $(425 \mathrm{~kg}$ SS/ha-y) is about the same as in Example 2 (450 kg SS/ha-y), requiring about the same area dedicated for the bioretention device (the reduced amount of runoff is balanced by the higher suspended solids concentration).

\section{Example 3}

A 1.0 ha rooftop in an area $\left(\mathrm{R}_{\mathrm{v}}=0.85\right)$ having $1.0 \mathrm{~m}$ of rain per year: $(10 \mathrm{mg} \mathrm{SS} / \mathrm{L})(0.85)(1 \mathrm{~m} / \mathrm{y})(1 \mathrm{ha})\left(10,000 \mathrm{~m}^{2} / \mathrm{ha}\right)\left(1,000 \mathrm{~L} / \mathrm{m}^{3}\right)(\mathrm{g} / 1,000$ $\mathrm{mg})$

$=85,000 \mathrm{~g} \mathrm{SS} / \mathrm{y}$ 
The unit area loading of suspended solids from this area is $85 \mathrm{~kg} \mathrm{SS} / \mathrm{ha}-\mathrm{y}$ and would only require a rain garden of about $0.06 \%$ of the roofed drainage area per year of operation, to maintain the $15 \mathrm{~kg} / \mathrm{m}^{2}$ loading limit.

\subsubsection{CEC (Cation Exchange Capacity) Calculations}

Much of the groundwater protection offered by soils is associated with its' cation-exchange capacity (Pitt, et al. 1996). The cation-exchange capacity (CEC) of a material is defined as the sum of the exchangeable cations it can adsorb at a given $\mathrm{pH}$. Alternatively, the CEC can be calculated as the measure of the negative charges present at the sorbent surface. The CEC is generally measured to evaluate the ability of certain soils to sorb $\mathrm{K}^{+}$(from fertilizers), heavy metals, and various other target ions whose mobility in the soil is an issue of concern. The CEC is a function of available surface charge per unit area of material, the $\mathrm{pH}$ at which exchange occurs, and the relative affinities of the ions to be exchanged for the material surface. The CEC is measured at a specific $\mathrm{pH}$. If the actual $\mathrm{pH}$ is less, the CEC also is less.

Sands have low CEC values, typically ranging from about 1 to 3 $\mathrm{meq} / 100 \mathrm{~g}$ of material. As the organic content of the soil increases, so does its' CEC content. Compost, for example, can have a CEC of between 15 and $20 \mathrm{meq} / 100$ grams, while clays can have CEC values of 5 and $60 \mathrm{meq} / 100$ grams. Natural soils can therefore vary widely in their CEC content depending on their components. Silt loam soils can have a CEC between 10 and 30 meq per 100 gram for example. Soil amendments (usually organic material, such as compost) can greatly increase the CEC of a soil that is naturally low in organic material, or clays.

Johnson, et al. (2003) conducted CEC measurements using standard methods, and also calculated the actual CEC based on the removal and exchange of all cations from a stormwater solution in a variety of filtration media. The capacity calculations confirmed the literature that indicated that peat moss, since it is often formed in calcium-poor conditions, had a high exchange/sorption capacity for calcium and for hardness (Table X-13). For peat, the quantity of cations exchanged was much greater than the standard $\mathrm{CEC}$ tests indicated. This likely was a result of the relatively large size of the test molecule for the CEC measurements (a copper trielthylenetetramine complex), which may not have been able to penetrate some of the micropores that the ionic forms of the metals and major ions could penetrate. 
Table 19.13 Calculated and measured CEC values for peat, sand, and compost.

\begin{tabular}{llll}
\hline & Sand & Peat & Compost \\
\hline Cation Exchange Capacity (calculated from batch tests) & 1.41 & 292 & 13.5 \\
\hline Cation Exchange Capacity (CEC analysis) & 3.49 & 21.47 & 18.83 \\
\hline Johnson, et al. 2003 & & &
\end{tabular}

The total cation content of a water sample can be easily calculated knowing the major ion content of the water and the associated equivalent weights, as shown on Table 19.14. The sum of the cations must equal the sum of the anions (expressed in equivalent weight). Table 19.14 is an example calculation for a typical stormwater.

Table 19.14 Example total cation content calculation for stormwater (Johnson, et al. 2003).

\begin{tabular}{llll}
\hline Component & $\mathrm{mg} / \mathrm{L}$ & Equivalent weight & $\mathrm{meq} / \mathrm{L}$ \\
\hline $\mathrm{Ca}^{2+}$ & 13.3 & 20.0 & 0.67 \\
$\mathrm{Mg}^{2+}$ & 3.3 & 12.2 & 0.27 \\
$\mathrm{Na}^{+}$ & 3.9 & 23.0 & 0.17 \\
$\mathrm{~K}^{+}$ & 2.3 & 39.1 & 0.06 \\
\hline & & Total cations: & 1.17 \\
\hline $\mathrm{HCO}^{3{ }^{3-}}$ & 36.7 & 61.0 & 0.60 \\
$\mathrm{SO}_{4}{ }^{2-}$ & 22.4 & 48.0 & 0.47 \\
$\mathrm{Cl}^{-}$ & 3.7 & 35.5 & 0.10 \\
\hline & & Total anions: & 1.17 \\
\hline
\end{tabular}

The above example only lists the major ions in the water. However, the concentrations of the dissolved heavy metals in stormwater are rarely more than about $0.10 \mathrm{mg} / \mathrm{L}$ and therefore contribute little to the total cation content of the water. The total (unfiltered) heavy metal concentrations of some metals can be much higher, but only the ionic forms affect the CEC. The total hardness of the above sample (the sum of the divalent cations) is $0.94 \mathrm{meq} / \mathrm{L}$, and with an equivalent weight of $50 \mathrm{meq} / \mathrm{L}$ per $\mathrm{mg} / \mathrm{L}$ as $\mathrm{CaCO}_{3}$, the resulting hardness concentration is about $47 \mathrm{mg} / \mathrm{L}$.

The consumption of the CEC in the soil can be calculated by dividing the soil total CEC by the total cation content of the water. If the soil is $1 / 2$ meter thick, and the soil density is about $1.5 \mathrm{grams} / \mathrm{cc}$, the total CEC of a soil having a CEC of $10 \mathrm{meq} / 100$ grams, per $\mathrm{m}^{2}$, is approximately 75,000 meq. If the stormwater has a total cation content of about $1.17 \mathrm{meq} / \mathrm{L}$, then the total 
water treatment capacity of the soil, per square meter, is about $64,000 \mathrm{~L}$, or a column of water about $64 \mathrm{~m}(210 \mathrm{ft})$ high. If the soil is only receiving rain water (having this cation content), and $1 \mathrm{~m}(3.3 \mathrm{ft})$ of rain falls per year, then the CEC content of the soil would be exhausted in about 60-70 y. The natural soil building process, and accumulating layers of organic material, would continue to "recharge" the soil CEC in an undeveloped setting, with very slow changes in the soil $\mathrm{CEC}$ with time. In an urban area infiltration device, the CEC of a soil could be exceeded much sooner, unless soil amendments are periodically added.

- Problem: Determine the approximate "life" of the CEC of a soil in an infiltration device having the following characteristics:

- the soil in an urban infiltration device has a CEC of $200 \mathrm{meq} / 100 \mathrm{~g}$ (averaged for $1 / 2 \mathrm{~m}$ in depth; soil dry density of $1.6 \mathrm{~g} / \mathrm{cm}^{3}$ ), - receives runoff from a paved area 30 times the area of the infiltration device,

- $1 \mathrm{~m}$ of rainfall a year, and paved area $\mathrm{Rv}$ of 0.85 , and

- the total cation content of the runoff water is $1.0 \mathrm{meq} / \mathrm{L}$

- Solution:

- total CEC content of soil $\left(\right.$ per $\left.\mathrm{m}^{2}\right)$ :

$0.5 \mathrm{~m}^{3} \times \frac{1.6 \mathrm{~g}}{\mathrm{~cm}^{3}} \times \frac{(100 \mathrm{~cm})^{3}}{\mathrm{~m}^{3}} \times \frac{200 \mathrm{meq}}{100 \mathrm{~g}}=1,600,000 \mathrm{meq}$

- total cation content of a years worth of runoff $\left(\right.$ per $\left.30 \mathrm{~m}^{2}\right)$ :

$30 \mathrm{~m}^{2} \times \frac{0.85 \mathrm{~m}}{\text { year }} \times \frac{(1000 \mathrm{~L})}{\mathrm{m}^{3}} \times \frac{1 \mathrm{meq}}{L}=\frac{25,500 \mathrm{meq}}{\text { year }}$

- therefore, the unit's CEC would be able to protect the groundwater for about $63 \mathrm{y}$., a suitable design period.

However, if the soil CEC was only $5 \mathrm{meq} / 100$ grams, then the facility would only protect the groundwater for about $3 \mathrm{y}$. In this case, either the infiltration device needs to be amended with organic material to significantly increase 
the CEC, the device should be made larger, the contributing paved area made smaller, or the soil will have to be replaced every several years.

\subsubsection{SAR (Sodium Adsorption Ratio) Calculations}

The sodium adsorption ratio can radically affect the performance of an infiltration device. Soils with an excess of sodium ions, compared to calcium and magnesium ions, remain in a dispersed condition, and are almost impermeable to rain or applied water. A "dispersed" soil is extremely sticky when wet, tends to crust, and becomes very hard and cloddy when dry. Water infiltration is therefore severely restricted. Dispersion caused by sodium may result in poor physical soil conditions and water and air do not readily move through the soil. An SAR value of 15 , or greater, indicates that an excess of sodium will be adsorbed by the soil clay particles. This can cause the soil to be hard and cloddy when dry, to crust badly, and to take water very slowly. SAR values near 5 can also cause problems, depending on the type of clay present. Montmorillonite, vermiculite, illite and micaderived clays are more sensitive to sodium than other clays. Additions of gypsum (calcium sulfate) to the soil can be used to free the sodium and allow it to be leached from the soil.

The SAR is calculated by using the concentrations of sodium, calcium, and magnesium (in meq) in the following formula:

$$
S A R=\frac{N a^{+}}{\sqrt{\frac{\left(C a^{+2}+M g^{+2}\right)}{2}}}
$$

The following example shows how the SAR is calculated:

A soils lab reported the following chemical analyses (the soil samples are typically taken as composites over the "plow" depth of about 6 in.):

100 pounds/acre of sodium $\left(\mathrm{Na}^{+}\right)$

5000 pounds/acre of calcium $\left(\mathrm{Ca}^{+2}\right)$

1500 pounds/acre of magnesium $\left(\mathrm{Mg}^{+2}\right)$

These concentrations need to be first converted to parts per million (ppm), and then to meq/L. An acre of soil $\left(43,560 \mathrm{ft}^{2}\right.$, or $\left.4,047 \mathrm{~m}^{2}\right), 6$ in. deep $(15$ $\mathrm{cm})$, weighs about $2,000,000$ pounds $(910,000 \mathrm{~kg})$ and contains $22,000 \mathrm{ft}^{3}$ of 
soil (620 cubic meters). The pounds reported per acre are divided by 2 to produce ppm (by weight):

100 pounds/acre of Na divided by $2=50 \mathrm{ppm}$ of Sodium

5000 pounds/acre of Ca divided by $2=2500 \mathrm{ppm}$ of Calcium

1500 pounds/acre of $\mathrm{Mg}$ divided by $2=750 \mathrm{ppm}$ of Magnesium

The ppm values are divided by the equivalent weight of the element (given previously in the CEC discussion) to obtain the relative milliequivalent (meq) values. The milliequivalent weights of $\mathrm{Na}, \mathrm{Ca}$, and $\mathrm{Mg}$ in this example are:

$50 \mathrm{ppm}$ of Na divided by $23=2.17 \mathrm{meq}$

$2500 \mathrm{ppm}$ of Ca divided by $20=125 \mathrm{meq}$

$750 \mathrm{ppm}$ of $\mathrm{Mg}$ divided by $12.2=61.5 \mathrm{meq}$

The SAR is therefore:

$$
S A R=\frac{2.17}{\sqrt{\frac{(125+61.5)}{2}}}=0.22
$$

This value is well under the critical SAR value of 15 , or even the critical value of 5 applicable for some clays. This soil is therefore not expected to be a problem. However, if the runoff water contains high levels of sodium in relationship to calcium and magnesium (such as snowmelt in areas using salt for de-icing control), an SAR problem may occur in the future, necessitating the addition of gypsum to the infiltration area. The amount of gypsum (calcium sulfate) needed to be added can be determined from an analysis of the soil in the infiltration area.

\subsection{Conclusions}

This discussion presented the steps proposed for calculating the water balance in an infiltration stormwater control practice. Also presented are typical soil and plant factors and several example calculations for different geometries (including parking lot bioretention devices, rain gardens, and green roofs) for different climatic conditions (hot and wet vs. hot and dry). The examples are not meant to be comprehensive indicators of the significance of the various soil processes, but to show how prior soil 
amendment and stormwater filtration media research can be used in this contest, especially as how this information can be incorporated into a stormwater quality model. Also discussed are features that will change with time (clogging, CEC consumption, and SAR effects on clays). The role of amendments to increase CEC content and ET water losses are also briefly described.

\section{Acknowledgments}

The authors wish to thank the contributions of others whose work was applied in this chapter. Research in the State of Wisconsin by the Dept. of Natural Resources, the USGS, and researchers at the University of Wisconsin, was extremely valuable in outlining the needs for this calculation protocol. Current research in Kansas City, MO, as part of an EPA-funded project to quantify the benefits of rain gardens and other bioretention facilities on combined sewer overflows, and research being conducted by the Facility for Advancing Water Biofiltration research center at Monash University, Melbourne, Australia, has also been beneficial in understanding the appropriate balance between complexity in bioretention system modeling and user needs. The authors also wish to acknowledge the thoughtful comments of the manuscript reviewers. Changes made at their suggestion have resulted in a clearer and more precise chapter.

\section{References}

Chin, D.A., Water-Resources Engineering, $2^{\text {nd }}$ edition. Prentice Hall, Upper Saddle River, N.J., 2006, 962 pages.

Clark, S.E. Evaluation of Filtration Media for Stormwater Runoff Treatment. M.S.C.E. Thesis, University of Alabama at Birmingham, Birmingham, Alabama, 442 pages. 1996.

Clark, S. and R. Pitt. Stormwater Treatment at Critical Areas, Vol. 3: Evaluation of Filtration Media for Stormwater Treatment. U.S. Environmental Protection Agency, Water Supply and Water Resources Division, National Risk Management Research Laboratory. EPA/600/R-00/016, Cincinnati, Ohio. 442 pgs. October 1999.

Clark, S. E. Urban Stormwater Filtration: Optimization of Design Parameters and a Pilot-Scale Evaluation. Ph.D. Dissertation, University of Alabama at Birmingham, Birmingham, AL. 2000.

Johnson, P.D., R. Pitt, S.R. Durrans, M. Urrutia, and S. Clark. Metals Removal Technologies for Urban Stormwater. Water Environment Research Foundation. WERF 97-IRM-2. ISBN: 1-94339-682-3. Alexandria, VA. 701 pgs. Oct. 2003. 
Kirby, J.T., and S.R. Durrans. PnET-II3SL/SWAT: Modeling the Combined Effects of Forest and Agriculture on Water Availability. ASCE Journal of Hydrologic Engineerin. 2006.

Pitt, R. Small Storm Urban Flow and Particulate Washoff Contributions to Outfall Discharges, Ph.D. Dissertation, Civil and Environmental Engineering Department, University of Wisconsin, Madison, WI, November 1987.

Pitt, R., with contributions from S. Clark, R. Field, and K. Parmer. Groundwater Contamination from Stormwater. ISBN 1-57504-015-8. Ann Arbor Press, Inc. Chelsea, Michigan. 219 pages. 1996.

Pitt, R.E. 1997. "Unique Features of the Source Loading and Management Model (SLAMM)." Journal of Water Management Modeling R200-02. doi: 10.14796/JWMM.R200-02.

Pitt, R., J. Lantrip, R. Harrison, C. Henry, and D. Hue. Infiltration through Disturbed Urban Soils and Compost-Amended Soil Effects on Runoff Quality and Quantity. U.S. Environmental Protection Agency, Water Supply and Water Resources Division, National Risk Management Research Laboratory. EPA 600/R-00/016. Cincinnati, Ohio. 231 pgs. December 1999.

Pitt, R.E. and J. Lantrip. 2000. "Infiltration Through Disturbed Urban Soils." Journal of Water Management Modeling R206-01. doi: 10.14796/JWMM.R206-01.

Pitt, R. and J. Voorhees. "SLAMM, the Source Loading and Management Model." In: Wet-Weather Flow in the Urban Watershed (Edited by Richard Field and Daniel Sullivan). CRC Press, Boca Raton. pp 103 - 139. 2002.

Pitt, R.E., S. Chen, S. Clark, J. Lantrip, C.K. Ong and J. Voorhees. 2003. "Infiltration Through Compacted Urban Soils and Effects on Biofiltration Design." Journal of Water Management Modeling R215-12. doi: 10.14796/JWMM.R215-12.

Pitt, R.E., R. Bannerman, S. Clark and D. Williamson. 2005a. "Sources of Pollutants in Urban Areas (Part 1) - Older Monitoring." Journal of Water Management Modeling R223-23. doi: 10.14796/JWMM.R223-23.

Pitt, R.E., R. Bannerman, S. Clark and D. Williamson. 2005b. "Sources of Pollutants in Urban Areas (Part 2) - Recent Sheetflow Monitoring." Journal of Water Management Modeling R223-24. doi: 10.14796/JWMM.R223-24.

Urbonas, B. Design of a Sand Filter for Stormwater Quality Enhancement. Water Environment Research, 71 (1), 102-113. 1996. 


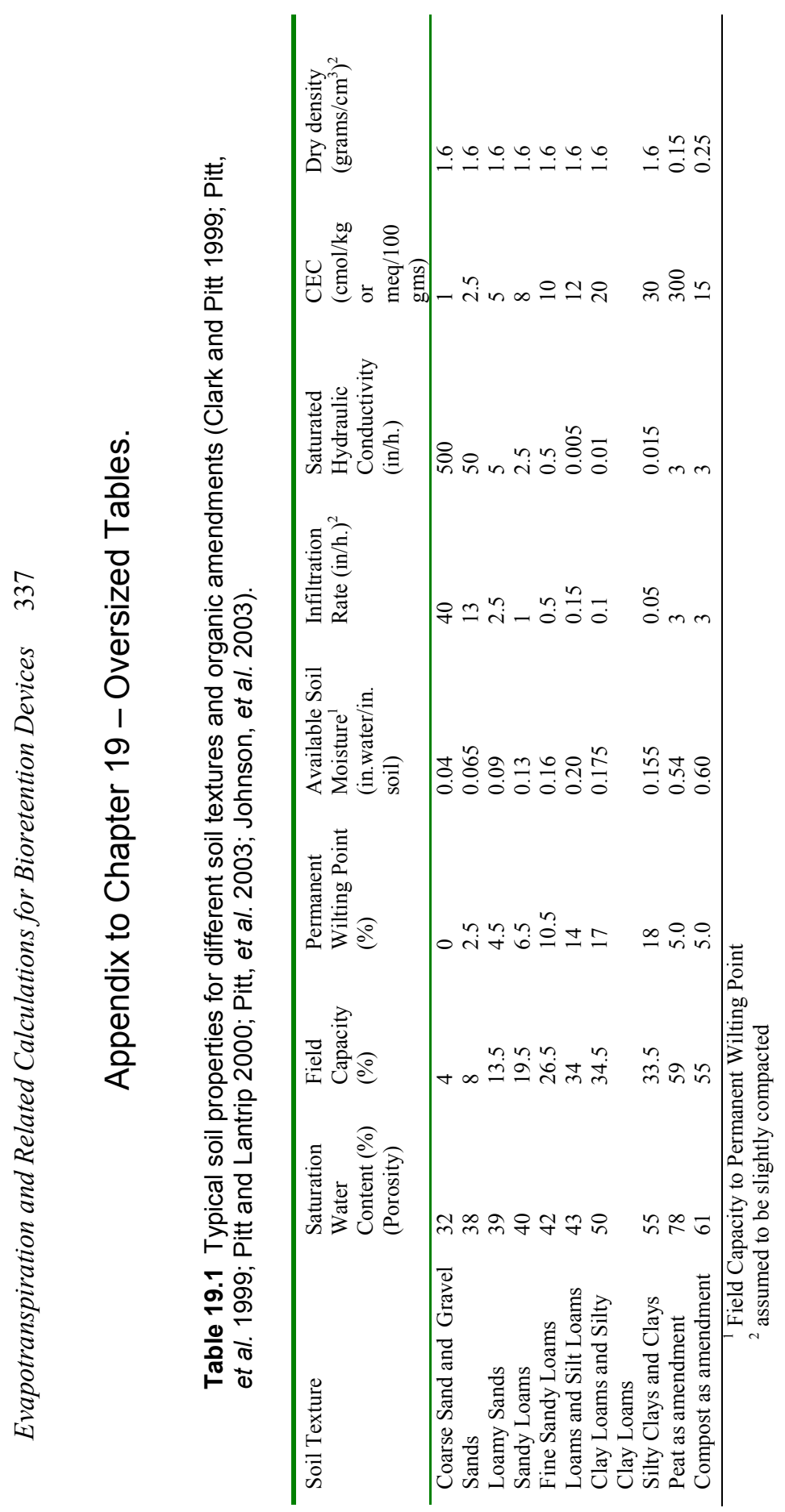




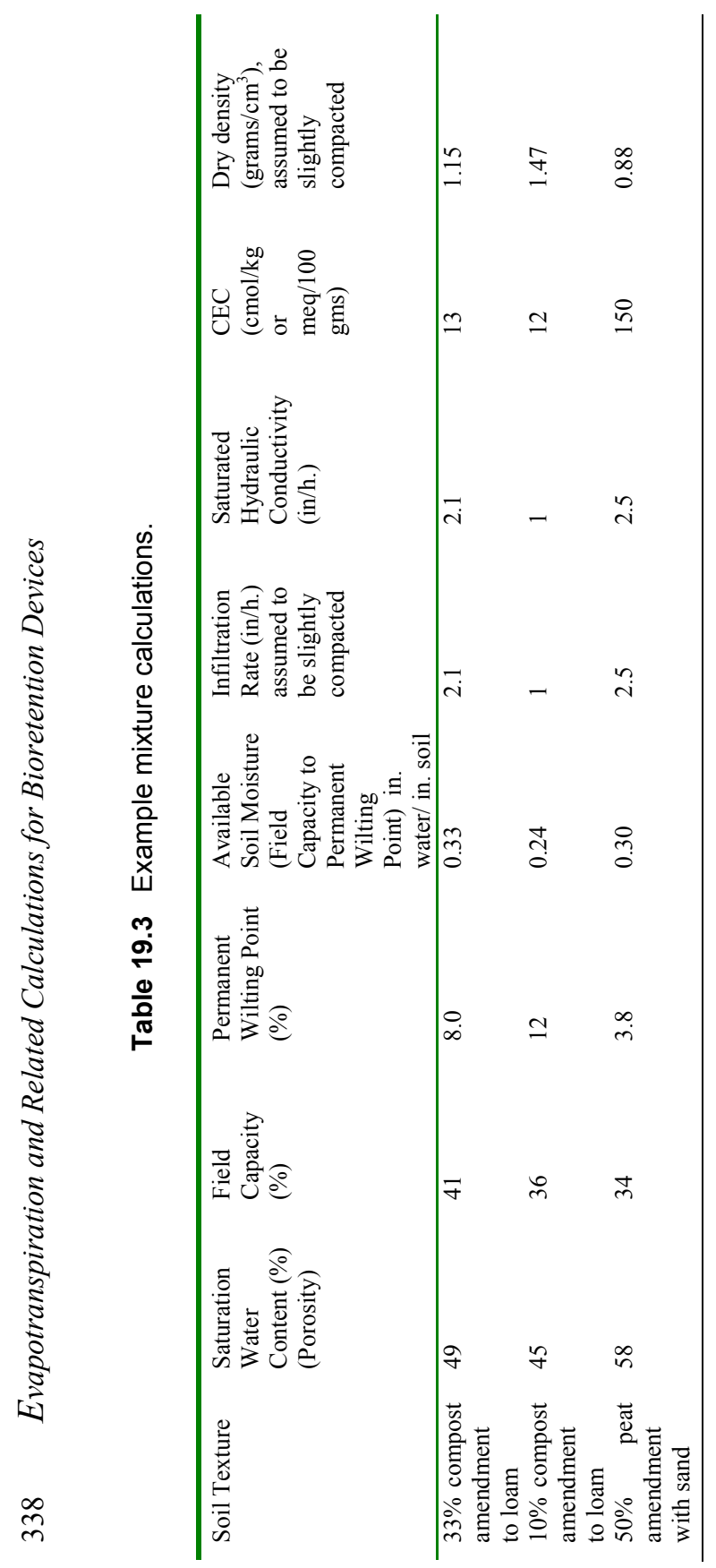




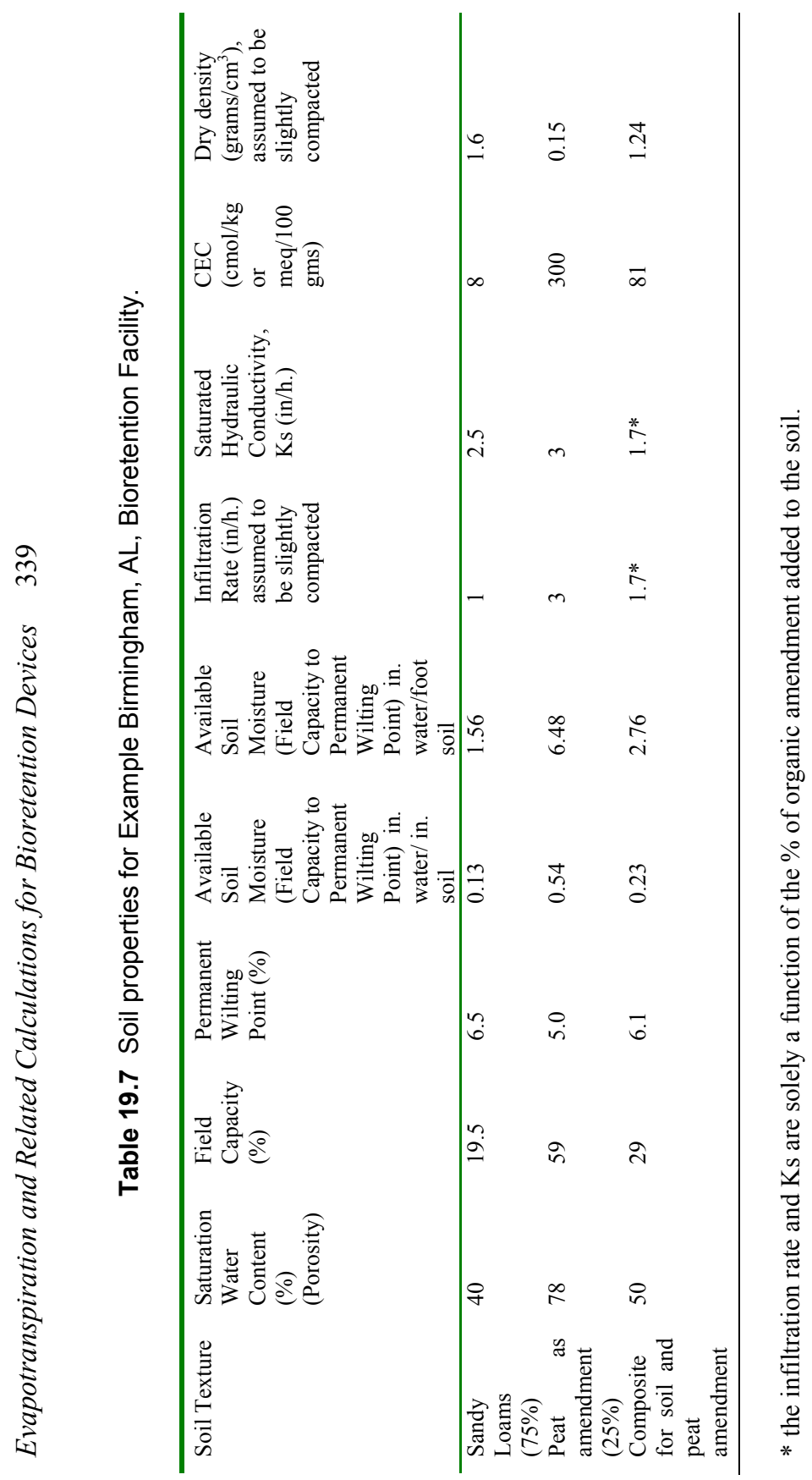




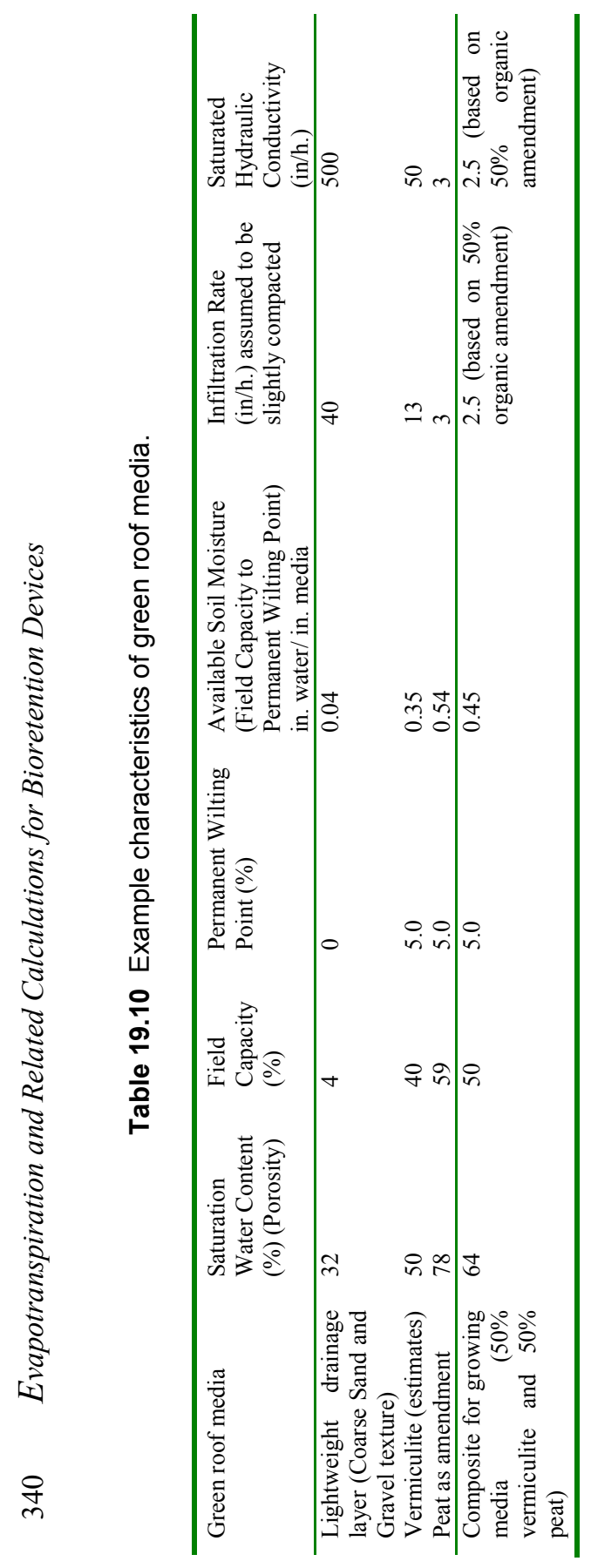

